Khatniuk Nataliia, Doctor of Laws, Associate Professor of Public and Private Law Faculty of Law and International relations Borys Grinchenko Kyiv University, 18/2, Bulvarno-Kudriavska str., Kyiv, 04053, Ukraine ORCID: 0000-0003-3064-7510

Pobiianska Nelli, $\mathrm{PhD}$ student of the Volodymyr the Great Educational and Scientific Institute of Law Interregional Academy of Personnel Management, 2, Frometivska str., Kyiv, 03039, Ukraine ORCID: 0000-0001-5872-9281

\title{
PROBLEMATIC ISSUES OF SOME WAYS OF PROTECTION THE RIGHTS AND INTERESTS OF ECONOMIC ENTITIES IN THE CONTEXT OF INTERNATIONAL LEGAL FRAMEWORK
}

This article identifies the main ways to protect the rights and legitimate interests of the parties of a business obligation, as well as proposes regulatory support for the additional guarantees for the rights of the above entities. The main issues of business development and new standards of activity and efficiency of economic entities in Ukraine are investigated. Positive trends of recent changes in business legislation are outlined.

Keywords: economic liability, contract, court, damages.

Хатнюк Наталія, Побіянська Неллі. Проблемні питання захисту прав та інтересів суб'єктів господарювання в контексті міжнародної правової мережі.

У иій статті визначено основні способи захисту прав і законних інтересів сторін господарського зобов'язання, а також подані пропозииї щодо нормативного закріплення додаткових гарантій забезпечення прав вище вказаних суб'єктів. Досліджено основні засади щодо забезпечення діяльності бізнесу та нові стандарти діяльності та відповідальності господарюючих суб'єктів в Україні. Позначено позитивні тендениії останніх змін господарського законодавства.

Ключові слова: господарське зобов'язання, договір, суд, збитки. 
Relevance of the research topic. Nowadays many significant events are taking place in the legal life of Ukraine, among which the author is going to highlight the signing on 7 August 2019 of the UN Convention on international agreements on the settlement of disputes by mediation with the participation of representatives from more than 70 countries. As noted by officials after its signing, this implementation will enhance the role of mediation, as an alternative to arbitration to resolve international commercial disputes, and generally have a positive impact on the development of international trade.

In the light of this, it is even more relevant to study current trends in the development of both judicial and extrajudicial ways of protecting their rights and interests of economic entities, as well as their implementation in the legal field of Ukraine. The implementation of protection their rights by economic entities and legitimate interests is based on the rules of commercial and civil law.

However, we must admit that the legislative framework, while regulating certain types of economic relations, does not allow to reach unambiguous conclusions and justify the decisions made by the judicial authorities.

At present, the lack of statutory regulation of certain types of economic relations and types of business activities and the regulation of others, hinder the stable and effective economical growth.

Formulation of the problem. Nowadays, there are no sufficient theoretical developments for the full and effective application of extrajudicial methods of protecting the rights of economic entities, and there are gaps in the normative provision of judicial protection of the above persons.

The main idea of the article is to study ways to protect their rights by economic entities and identify problematic issues in their application, substantiation of proposals for their improvement and development.

Analysis of recent research and publications. In analyzing the positions and approaches to reforming the legislation governing economic relations, we support the idea of V. Shcherbyna on strengthening the key role of the Economic Code of Ukraine in all spheres of legal regulation of economic relations (Shcherbina, 2016). It is necessary to take into account the fact that the codification of the general provisions of the legal regulation of economic relations took place on the basis of a number of noncodified acts.

Continuation of further codification processes is possible only in the light of changes in basic statutory instrument, which emphasizes the need for modernization of legislation (Shcherbina, 2016, p. 182).

This opinion is also supported by A. Zamryga, justifying the updating of economic legislation not by increasing and dispersing its norms, which will not allow effective implementation of economic policy, but in the direction of its codification, which implies, in particular, a reduction in the number of blanket norms and simultaneous supplementation with norms of direct action and references to specific laws (Zamryha, 2016, p. 64). 
Currently, in the scientific environment, there is such an opinion, which is advocated, in particular, by V.Petrunia, and the author agrees with it, to give to the party of an economic obligation the ability to request the enforcement, with a number of clearly established legislative exceptions, that would cut off claims for enforcement already at the stage of trial. But we cannot agree that obligations that inherently require the lender to be able to use for protection of his rights and interests such protection as the award of a debt in kind are primarily the legal relationship, in which the debtor enterprises - solely monopolists in the market - are acting in the obligation to perform works or provide services. After all, in such relations the creditor cannot entrust the execution to third parties due to the absence of other entities, which are providing such services in the market (for example, transportation by rail, etc.), or when the performance of works or provision of services is related to the person of the executor (Petrunya, 2019, p. 14).

We believe that the use of the term «monopolist» will practically negate the application of this provision. N. Ivanyuta distinguishes such a way of protection of the rights of the parties to economic agreements as notarial protection, considering it as a set of forms, means and measures of an alternative nature, which are carried out by the authorized bodies of the state, in resulting in the proper exercise of rights, in particular, to qualified legal assistance, the prevention or elimination of opportunities for infringement of rights, the restoration of violated rights of economic entities (Ivanyuta, 2018).

We agree with the researcher and believe that the involvement of notaries is undoubtedly a positive phenomenon that is in line with global trends. With the purpose to the practical extrajudicial protection of the rights of economic entities from November 26, 2014, the Business Ombudsman Council (Postanova Kabinetu Ministriv Ukrayiny' № 691, 2014) started operating in Ukraine as an anti-corruption initiative, agreed between the Government of Ukraine, the European Bank for Reconstruction and Development, the OECD and Ukrainian business associations. The activities of this council are aimed at preventing of possible violation of human rights by the economic entities themselves. However, in the opinion of the author, the activity of the above-mentioned council is advisory and needs to be fixed and regulated at the legislative level. As of today, it can not only submit appeals to other bodies of authority and officials in order to resolve issues presented in the complaint to this council.

Presenting main material. The Institute for the Protection of rights of economic entities has its own specificity and its own peculiarities. Part 2 of Article 16 of the Civil Code of Ukraine establishes ways of protecting civil rights and interests, namely: recognition of rights; recognition of a juristic act invalid; termination of the infringing action; restoration of the situation that existed before the violation; 
compulsory discharge of duty in kind; change of legal relationship; termination of legal relationship; compensation for damages and other methods of compensation for property damage; compensation for moral (non-pecuniary) damage; the recognition of the decisions, actions or omissions of a public authority or local self-government body, their officers and officials. The court may protect civil law or interest in another way established by contract or by law (Cy'vil'ny'j kodeks Ukrayiny').

Analyzing the rules of the Civil and Economic Codes, we agree with the opinion of Fedorenko T.V. that by comparing the norms of the Civil Code of Ukraine, namely Art. 16, which sets out the methods of protection of civil rights and interests, and the norms of the Commercial Code of Ukraine, Art. 20, defining the ways (means) of protecting the rights of economic entities, we see that 1) both codes contain an exhaustive list of ways of protecting the violated rights and interests; 2) the methods of protection of rights and interests established by both codes differ in volume, content and titles.

The main difference between the above-mentioned articles of the Civil and Economic Codes of the methods of protection of rights and interests concerns «recognition of the right» (Fedorenko, 2016, p. 142). In our opinion, they should be agreed first.

In June 2011, the United Nations Human Rights Council adopted the Business Guidelines, which were the impetus for setting new standards for the activities and responsibilities of businesses, and in Ukraine in particular.

In our view, in light of the issue under consideration, it is necessary to draw attention to Guideline 31, which states that, in order to ensure the effectiveness of state and non-state out-of-court complaint mechanisms, the following should be guaranteed: (a) legitimacy: ensuring the credibility of the stakeholder groups to which these mechanisms are intended, their accountability in terms of the fairness of the grievance processes; (b) accessibility: ensuring that all stakeholder groups targeted by these mechanisms are informed and that appropriate assistance is provided to parties whose access to the relevant mechanisms is hampered by specific barriers; (c) predictability: ensuring a clear and comprehensible procedure indicating the oriented timing of each step, as well as clarifying the types of process available, the results and the means of monitoring the implementation of decisions; (d) fairness: the desire to ensure that the parties involved have reasonable access to the sources of information, advice and expertise necessary to participate in the complaint, based on the principles of fairness, awareness and respect (Special Representative, 2011).

In order to prevent violations of the rights of the parties of the economic obligations, in accordance with generally accepted world practice, the author proposes to fix in the Commercial Code, as a prerequisite for the conclusion of any kind of contracts, the principle of «due diligence». 
Currently, there are no regulatory mechanisms for ensuring due diligence on the part of the parties to the obligation, and there are no clear recommendations for its compliance. We may meet DUE DILIGENCE (ensuring due diligence) service announcements by many law firms, but in most cases they are part of the legal support of merger and acquisition agreements only. This practice, in the author's opinion, is positive; it requires its regulatory support, further development and application to a much wider range of economic contracts, and as a studying of the real state of the economic entity, studying and taking measures to minimize the real risks of fulfilling the obligation.

Likewise, the author proposes to include in the list of sanctions for a significant (such that it is extremely disadvantageous to the other party to the economic agreement) breach by a party of an economic obligation such as limiting access to certain types of financing, such as state or the right to participate in tendering, obtaining state aid, the right to participate in the privatization of state property, conclude concessions, participate in projects of state-legal partnership.

The mediation procedure is recognized as an effective mechanism for the restoration of human rights violations. Nowadays, the Law of Ukraine "On Mediation» is only a project, but its adoption is time consuming. We believe that its practical implementation will reduce the number of cases before the courts and allow the majority of conflict situations to be resolved in the pre-trial order, which will undoubtedly have a positive impact on the economic turnover.

According to the author, it is necessary to stipulate at the level of the code, as an essential condition of the obligation, a mediation clause, which will regulate the main provisions of its conducting and implementation of the agreements reached, in particular, voluntary payment of fines and compensation of the damages, without the conclusion of additional contracts or agreements.

Conclusion. It is necessary to note all the positive initiatives and shifts that are aimed at preventing and restoring the rights of economic entities carried out in contact and in accordance with international standards. But further intensity and complication of economic turnover in Ukraine can no longer be satisfied with the existing rules of the Civil and Economic Codes of Ukraine.

We conclude that, it is necessary to carry out further revision of the provisions of the Economic Code of Ukraine and to make appropriate changes, in particular, giving the parties of economic obligations the opportunity to operate a full mechanism of mediation procedures and the possibility of paying fines and damages independently without concluding additional agreements. 


\section{REFERENCES}

1. Cy’vil’ny’j kodeks Ukrayiny’, 16 sichnya 2003 roku № 435-IV - Vidomosti Verxovnoyi Rady' Ukrayiny' 2003, № 40-44, st. 356 [Civil Code of Ukraine, January 16, 2003 No. 435-IV. Bulletin of the Verkhovna Rada of Ukraine 2003, No. 40-44, 356 p.]. [in Ukrainian].

2. Fedorenko, T.V. (2016) Forms and ways of protecting the rights and legitimate interests of economic entities. Comparative and Analytical Law. No. 5.

3. Petrunya, V.V. (2019). Ponyattya ta sy'stema sposobiv zaxy'stu prav sub'yektiv gospodaryuvannya. The dissertation author's abstract on obtaining a scientific degree of candidate of law sciences. Retrieved from http://dspace.onua. edu.ua/bitstream/handle/11300/11341/Petrunia_avtoref.pdf?sequence=3\&isAllowed=y. [in Ukrainian].

4. Postanova Kabinetu Ministriv Ukrayiny’ № 691 vid 26.11.2014 roku «Pro utvorennya Rady' biznes-ombudsmena». [Resolution of the Cabinet of Ministers of Ukraine № 691 of 11.26.2014 «On the formation of the Business Ombudsman Council»]. Retrieved from https://zakon4.rada.gov.ua/laws/show/691-2014-\%D0\%BF. [in Ukrainian].

5. Special Representative of the Secretary-General on the Issue of Human Rights and Transnational Corporations and Other Business Enterprises, Guiding Principles on Business and Human Rights: Implementing the United Nations «Protect, Respect and Remedy» Framework, Annex, U.N. Doc. A/HRC/17/31 (Mar. 21, 2011) (by John Ruggie).

6. Ivanyuta, N.V. (2018). Pozasudovi formy' zaxy'stu prav ta vy'rishennya gospodars'ky'x sporiv. Scientific Bulletin of Uzhgorod National University, Law series, Issue 49, Volume 1. [in Ukrainian].

7. Shcherbina, V. (2016). Modernizaciya gospodars'kogo zakonodavstva. Actual Problems of Domestic Jurisprudence. № 5. [in Ukrainian].

8. Zamryha, A. (2016). Problematy'ka onovlennya gospodars'kogo zakonodavstva v konteksti Ugody' pro asociaciyu mizh Ukrayinoyu ta EU. Enterprise, Economy and Law. № 6. [in Ukrainian]. 